811.163.41'27

316.644- 057.874:811.163.41'282

https://doi.org/10.18485/sj.2018.23.1.33

НИНА Љ. СУДИМАЦ*

Филозофски факултет

Универзитет у Нишу
Оригинални научни рад

Примљен: 04. 01. 2017.

Прихваћен: 29. 01. 2018.

\title{
СТАВОВИ СРЕДњОШКОЛАЦА ПРЕМА ОСАМ УРБАНИХ ВАРИЈЕТЕТА СРПСКОГ ЈЕЗИКА
}

Ставови према језичким варијететима представљају веома важне факторе у друштвеној интеракцији и тесно су повезани са перцепцијом друштвеног статуса (моћи) и солидарности (блискости), посебно када су у питању прозодијска обележја говора. У раду су представљени ставови 102 средњошколца са подручја Ниша и Блаца према осам различитих урбаних варијетета српског језика. За потребе истраживања снимљено је осам изворних говорника различитих варијетета, те је индиректним и директним методама показано да се експлицитни и имплицитни ставови испитаника разликују и да начин говора поједница утиче на перцепцију од стране испитаника и додељивања особина у погледу друштвеног статуса, солидарности и лингвистичких перформанси говора.

Кључне речи: ставови према језичким варијететима, експлицитни и имплицитни ставови, особине, друштвена моћ, солидарност, исправност, социолингвистика, српски језик.

\section{1. УВОД}

Језичка разноликост људи који живе у истој земљи или истом граду појава је која је уочљива свима и привлачи пажњу многих људи - не само језичких стручњака. Разлике могу бити присутне на свим језичким нивоима 
и представљају богату подлогу за многобројна истраживања која захтевају уплив социјалних и психолошких теорија. Већина говорника је у стању да после једне реченице процени одакле долази саговорник и да на основу тога, често, формира став према њему: може се говорити о великом броју фактора који утичу на стварање слике о одређеној особи, почевши од поднебља са кога саговорник долази и његовог говора, преко низа других социјалних и психолошких елемената који имају важно место у формирању утиска. Ставови према говорницима са нестандардних подручја поготово су повезани са економским, социјалним и културним одликама региона са кога су поникли. Већина истраживања из области социолингвистике, социофонетике, психологије и примењене лингвистике, показала су да ставови према језику имају веома важну улогу у друштвеној интеракцији и зато је неопходно проучавати их.

У нашој литератури највише пажње посвећено је испитивању различитих варијетета ${ }^{1}$ насталих просторним, географским раслојавањем (дијалекти). Са друге стране, насупрот вертикалној стратификацији постоји и хоризонтална, која се односи на појаву различитих варијетета на истом географском подручју условљених неким ванлингвистичким, социјалним елементима: образовањем појединца, професијом, друштвеном припадношћу или жељом да се говорним елементима направи дистанца од друштвене заједнице и постигне различитост (социолекти). Одређени друштвени услови, односно окружење, контекст, диктирају на који начин ће појединци говорити, односно да ли ће доћи до промене кода: ${ }^{2}$ на један начин говориће са пријатељима, укућанима, људима са којима су билски, а на другачији са непознатим особама или на местима која захтевају службену употребу језика.

\section{2. ПРЕТХОДНА ИСТРАЖИВАњА}

Говорећи о различитим варијететима који постоје у језику, долази се до главне синтагме која је и тема рада - ставови према језику, односно према различитим варијететима једног језика. Ставови према језику и њихво проучавање спадају у ред веома битних социолингвистичких подручја. Најбројнији радови баве се испитивањем ставова према различитим варијететима енглеског језика у којима су аутори проучавали ставове према стандардним и нестандрадним варијететима енглеског на подручју Сједињених Америчких Држава и Уједињеног Краљевства (Милрој 2001; Хауард и Купланд 1991). Језички ставови - обухватајући когнитивну, афективну и емоционлану компоненту,

${ }^{1}$, „Bapujemem је обухватан и неутралан термин којим се у социолингвистици упућује на било који групно одређени појавни облик неког језика, било то одређење географско, социјално или какво друго.” (Бугарски 2009: 23).

${ }^{2}$ Према енглеском термину code switching. 
профилишу личност и веома су добри показатељи онога што појединац заправо и јесте. Ипак, ставови некада не могу бити прави и реални показатељи нечије личности: многа истраживања су показала да се експлицитно исказани ставови разликују од имплицитних, што се одражава и на језик (Гарет, Купланд и Вилијамс 2003).

Друга важна ствар везана је за постојање стереотипа према одређеним варијететима, о чему говоре истраживања вршена на примеру енглеског језика (Гарет, Купланд и Вилијамс 2003; Купланд и Бишоп 2007; Хирага 2005).

Треће гледиште у проучавању језичких ставова тиче се постојања двеју димензија у које се сврставају људи са стандардних и нестандардних језичких подручја: испитаници су склони да оним првим говорницима приписују особине које су друштвено пожељне, које се тичу друштвене моћи, угледа, статуса, док другима приписују особине емоционалне блискости и солидарности. Истраживања су вршена на примеру енглеског језика (Лабов 1972а,б; Лејдгард 1998; Мекензи 2008; Традгил 1983; Фергусон 1991; Хирага 2005) и сви аутори су закључивали следеће: да се стандардни варијетети оцењују високо у смислу престижа, а нестандардни високо у смислу солидарности.

Један од разлога зашто смо одлучили да се бавимо овом темом лежи у малобројности емпиријских истраживања када је реч о српском језику (Васић 1994; Књижар 2011; Ковачевић 2004, 2005; Пауновић 2007а,б, 2008, 2009а; Средојевић 2011). У овом раду приказаћемо део резултата обимног истраживања која се односе на ставове средњошколаца из Ниша и Блаца према урбаним варијететима матерњег језика.

\section{3. ИСТРАЖИВАЬЕ}

Главни циљ овог рада био је испитати ставове српских средњошколаца према урбаним варијететима српског језика. Основна питања на којима је засновано истраживање била су:

1. Какве ставове имају средњошколци према различитим варијететима матерњег језика?

2. Да ли се експлицитно и имплицитно исказани ставови разликују?

3. Какве особине средњошколци додељују говорницима на основу нагласних карактеристика њиховог говора, у домену друштвеног статуса, солидарности и језичке правилности?

4. Да ли постоји статистички значајна разлика између ставова које исказују средњошколци у Блацу и Нишу? 


\section{1. Избор варијетета и селекција говорника}

У истраживању смо испитивали ставове средњошколаца према апатинском, суботичком, новосадском, београдском, крушевачком, блачком, нишком и пиротском варијетету. ${ }^{3}$ Како смо одлучили да се бавимо ставовима испитаника према фонетским, односно нагласним особинама у варијететима (нису узете у обзир морфолошке, синтаксичке или лексичке особине) сматрамо да је избор варијетета прилагођен овом истраживању. Сви одабрани варијетети представљају екавске говоре. У наредним пасусима даћемо општи опис прозодијских особина одабраних варијетета, који ће показати зашто је избор ишао у овом правцу.

Прву групу чине новоштокавски варијетети - апатински, суботички, новосадски и београдски. Међу њима можемо издвојити прва три као северне говоре, тачније апатински као северозападни. Специфичност места проистиче из струкуре становника који су у највећем проценту досељеници из личких крајева, те и њихов говор чува одлике места одакле потичу: извршено је новоштокавско, метатонијско преношење акцената (четвороакценатски систем), чувају се постакценатске дужине, преношење акцената на клитике је живо, тако да „се бачки говори одликују блискошћу са источнохерцеговачким дијалектима и са српскохрватским књижевним језиком” (Ивић 1994: 167). У новосадском и суботичком варијетету преношење акцената на клитике је недоследније у односу на источнохерцеговачке (Бошњаковић 2009: 79). Ови говори захваћени су процесом уклањања неакцентованих дужина 4 (Суботић 1995), а као посебна карактеристика и препознатљивост издваја се посебан изговор неких вокала: „кратки вокали / $\breve{e} /$ и /ŏ/ већином се изговарају веома отворено... док је отворен изговор присутан и код /u/ независно од квантитета" (Ивић 1994: 166). Београдски варијетет је најтеже дефинисати због специфичности поднебља на коме живи велики број досељеника из различитих крајева. Можемо говорити о успостављању једног урабног варијетета од стране млађих становника.

У другој групи налазе се староштокавски (косовско-ресавски) варијетети - крушевачки и блачки, који чувају старо акцентогено место и у којима постоје краткосилазни, дугосилазни и дугоузлазни акценат (и акут у говору Блаца), као и предакценатске дужине. Типична фонетска црта крушевачког варијетета огледа се у отворености вокала по чему се становници увек препознају, док је у блачком варијетету отвореност вокала нешто мања.

\footnotetext{
${ }^{3}$ Према саветима Т. Пауновић у истраживање нисмо укључили представнике централне и западне Србије, јер ставови према тим варијететима захтевају посебно испитивање (Пауновић 2009б: 82).

4 Чувају се иза краткоузлазног акцента у финалном затвореном и медијалном слогу (Бјелаковић и Марковић 2009: 123).
} 
У последњој групи налазе се два призренско-тимочка варијетета - нишки и пиротски, који генетски припадају штокавским говорима, али су у великој мери и одвојени од њих продирањем тзв. балканизама. Описујући јужне српске говори, Ивић бележи следеће: „У говорима ове зоне истрвене су све квантитативне опозиције [...] а такође изостају и квалитативне (интонационе) опозиције (силазни : узлазни акценти). Има, дакле, само један акценат, експираторичан по карактеру, без обавезних квантитативних или тонских обележја, чији изговор може варирати трајањем и тоном само у зависности од реченичке интонације... Место акцента је слободно.” (Ивић 1985: 112). У говору млађих представника нишког варијетета уочавамо тежњу ка померању акцентогеног места за један слог унапред са специфичним дужењем наглашеног вокала (помЕрили : померИли). Селекција говорника извршена је према три критеријума: регионалном пореклу, узрасту и полу ${ }^{5}$.

\section{2. Методологија}

У истраживању је коришћен мешовити приступ. Директном методом - помоћу упитника, добијени су социодемографски подаци учесника (пол, старост, место рођења, место живљења), као и одговори на директно постављена питања у вези са ставовима према различитим варијететима српског језика. Питања су била затвореног типа, а одговори су били петостепени ( $\partial а$, углавном $\partial a$, понекад, углавном не и не) и захтевано је да се одговори заокруживањем искључиво једног од пет понуђених одовора. Индиректни приступ односио се на коришћење технике говорних представника̂ (verbal guise techniqe). ${ }^{6} \mathrm{y}$ нашем истраживању користили смо технику говорних представникаิ. Осам различитих женских особа прочитало је један исти текст - спонтано, онако како разговарају у свакодневној комуникацији. Текст је био кратак (60") како испитаници не би били заморени слушањем дугог текста.

Основно средство за процену говорних узорака била је седмостепена семантичко-диференцијална скала у којој су са леве стране били позитивни придеви, а са десне њихови негативни парњаци. ${ }^{7}$ Придеви су одабрани на основу постојећих примера у литератури (Лејдгард 1998; Мекензи 2008; Хирага 2005), али су притом модификовани и прилагођени српској традицији и

\footnotetext{
${ }^{5}$ У питању су младе особе (од 18 до 25 година), типични представници поменутих варијетета, истог пола (женског) - контролисана је ова варијабла како приликом оцењивања говора учесници не би били пристрасни и вршили полну дискриминацију.

${ }^{6}$ Употребљени термин представља превод са енглеског, који је аутор рада прилагодио српском језику: ова техника подразумева учешће већег броја говорника за представљање различитих варијетета, насупрот старијој (matched guise technique) у којој је један говорник представљао све варијетете.

${ }^{7}$ То значи да је 1 била најпозитивнија оцена, а 7 најнегативнија. Сви примери били су у женском роду, у номинативу једнине.
} 
култури. Придеве смо поделили у три групе: први демонстрирају друштвено пожељне особине, оне које се односе на моћ, статус и углед у друштву; други се односе на солидарност, блискост и пријатељство; трећи су лингвистичке природе и односе се на језичку исправност и „стандардност”. Упарени придеви из групе друштвено пожељних особина били су: образована - необразована, интелигентна-неинтелигентна, успешна-неуспешна, стручна-нестручна; у другој групи нашли су се следећи придеви: дружељубива - недружељубива, искрена - неискрена, поузана - непоудана, духовита - недуховита; трећу групу (према Лејдгард 1998) чинили су следећи придеви: исправно говори - неисправно говори ${ }^{8}$, пријатна - непријатна, стандардно говори - нестандардно говори, разумљива - неразумљива.

\section{3. Спровођење експеримента}

У експерименту су учествовала 102 субјекта - 51 жена и 51 мушкарац, у распону од 16 до 19 година. Од укупног броја, 48 испитаника је из Ниша, а 54 из Блаца. Истраживање је спроведено у Гимназији 9. мај у Нишу и Средњој школи у Блацу, у јануару 2016. године, уз компјутерску опрему и потпуну анонимност свих испитаника. Сви подаци обрађени су квантитативним путем уз помоћ програма за статистичку обраду података SPSS (верзија 20.00). Квантитативна анализа добијених података садржала је дескриптивну статистику (фреквенције и мере централне тенденције). $T$ тест је коришћен за поређење дијалекатске припадности, док је Пирсонов тест коришћен онда када смо желели да видимо има ли статистички значајних корелација у истраживању. Извршена је и анализа поузданости упитника по алфа моделу - и у целини и за групе повезаних питања (Reliability Analysis Scale Alpha) и утврђен је Кронбахов алфа коефицијент (Cronbach's Alpha). ${ }^{9}$

\footnotetext{
${ }^{8}$ Напомена: Придеви исправно говори и стандардно говори узети су из разлога процене и утврђивања њихове семантике: желели смо да видимо да ли испитаници исправност и стандардност доживљавају као синониме, тј. придеве са истим значењем и да ли ће их у позитивном облику додељивати свим новоштокавским говорницима или ће ту правити разлику.

${ }^{9}$ Целокупни тест има алфа $=0,899$ (за осам узорака говора), док је алфа $=0,897$ за сваки појединачни ајтем. Поузданост појединих група питања за 8 говорних подручја: код друштвено пожељних особина алфа $=0,768$, док је поузданост преко 0,751 за сваки појединачни ајтем ове групе питања. У групи особина које се односе на солидарност алфа $=0,730$, док је поузданост преко 0,710 за сваки појединачни ајтем ове групе питања. На крају, код групе особина које се односе на језичку тачност алфа $=0,815$, док је поузданост преко 0,802 за сваки појединачни ајтем ове групе питања.
} 
Табела 1. Средње вредности за дванаест оиенениваних особина (на укупном узорку)

\begin{tabular}{|c|c|c|c|c|c|c|c|c|}
\hline Особине & Београд & Крушевац & Нови Сад & Пирот & Апатин & Блаце & Суботица & Ниш \\
\hline Образована & 1,7843 & 4,9706 & 2,0000 & 5,4902 & 2,2255 & 4,9706 & 1,9314 & 4,5294 \\
\hline Дружељубива & 4,2059 & 2,5294 & 4,5294 & 2,7255 & 4,6961 & 2,7843 & 4,6667 & 2,3235 \\
\hline Интелигентна & 2,2549 & 4,9314 & 2,0980 & 5,2353 & 2,2451 & 4,9902 & 2,0882 & 4,4902 \\
\hline Искрена & 4,5392 & 2,2843 & 4,8431 & 2,5392 & 4,9510 & 2,5686 & 4,8725 & 2,2353 \\
\hline Успешна & 2,0588 & 5,0784 & 2,1078 & 5,4118 & 2,3725 & 5,0784 & 2,0392 & 5,2549 \\
\hline Поуздана & 4,8333 & 2,6275 & 5,5196 & 2,7647 & 5,0588 & 2,4608 & 5,0294 & 2,3725 \\
\hline Стручна & 2,2549 & 5,4902 & 2,5490 & 5,7451 & 2,4608 & 5,5000 & 2,4020 & 5,0686 \\
\hline Духовита & 5,9706 & 2,4804 & 6,0882 & 1,9804 & 6,0392 & 2,4020 & 6,0098 & 2,0000 \\
\hline Исправна & 1,5686 & 5,3824 & 2,0098 & 6,1863 & 1,9314 & 5,0098 & 1,8431 & 4,6275 \\
\hline Пријатна & 2,5588 & 3,5588 & 2,6961 & 4,0882 & 3,1863 & 4,3137 & 2,7255 & 3,1373 \\
\hline Стандардна & 2,1569 & 4,8824 & 2,1667 & 5,6667 & 2,0294 & 4,5490 & 2,0980 & 4,4510 \\
\hline Разумљива & 1,5784 & 2,8039 & 1,8333 & 3,7941 & 1,8725 & 2,8235 & 1,7451 & 2,5294 \\
\hline
\end{tabular}




\section{4. АНАЛИЗА РЕЗУЛТАТА СПРОВЕДЕНОГ ИСТРАЖИВАЮА И ДИСКУСИЈА}

\section{1. Први део истраживања: семантичко-диференцијалне скале}

У Табели 1 налазе се резултати средњих вредности за свих дванаест поједниначно испитиваних придева, док Табела 2 доноси резултате средњих вредности груписаних придева у домене друштвене пожељности, солидарности и језичке исправности - направљена је због прегледности и глобалнијег увида у резултате.

Како резултати показују, испитаници су београдски варијетет оценили као најповољнији у погледу друштвене пожељности, док је као најнеповољнији виђен пиротски варијетет. Новосадски, апатински и суботички варијетети оцењени су приближно - повољно у смислу пожељности и атрактивности. Са друге стране, најповољније оцењен варијетет у погледу солидарности и присности је нишки, док су испитаници новосадски видели као њима најмање близак. Београдски варијетет заузима прво место и када су у питању лингвистичке перформансе и ,,језичка исправност”, док је пиротски варијетет поново на последњем месту - виђен је као најмање исправан. Анализа резултата средњих вредности за појединачне придеве, негруписане, показује да београдски варијетет није у свим сегментима друштвено пожељних придева оцењен као најповољнији - јесте, када говоримо о образованости и успешности, али не када је у питању интелигентност и стручност. У тим сегментима је најповољније оцењен суботички варијетет, док је пиротски оцењен као најнеповољнији.

Чињеница да су испитаници београдски варијетет видели као најисправнији и да је заузео прво место у лингвистичком погледу указује на то да је, можда, најмања регионална маркираност била главни параметар за додељивање високих оцена поменутом варијетету. Анализа резултата појединачних придева показује да испитаници не доживљавају исто појам исправности и стандардности (други придев је додељен суботичком варијетету), што наводи на размишљање да су средњошколци стандардност оцењивали на основу знања о томе који је варијетет узет за основицу стандардног српског језика. Такође, анализом добијених скорова на нивоу појединачних особина видимо да је разумљивост најповољније оцењивана у односу на остале ,језичке” придеве, што је и очекивано јер су у питању варијетети матерњег језика. Детаљнија и дубља анализа добијених резултата показује да су језичка тачност и стандардност неповољније оцењене него образованост и успешност - дакле, испитаници оно што цене високо по успеху и статусу, ипак не цене у истој мери као језички тачно. 
Табела 2. Средње вредности за дванаест особина груписаних у три подручја - на нивоу укупног узорка

\begin{tabular}{|c|c|c|c|c|c|c|c|c|}
\hline $\begin{array}{c}\text { Груписа- } \\
\text { но }\end{array}$ & $\begin{array}{c}\text { Бео- } \\
\text { град }\end{array}$ & $\begin{array}{c}\text { Кру- } \\
\text { шевац }\end{array}$ & $\begin{array}{c}\text { Нови } \\
\text { Сад }\end{array}$ & Пирот & $\begin{array}{c}\text { Апа- } \\
\text { тин }\end{array}$ & Блаце & $\begin{array}{c}\text { Субо- } \\
\text { тица }\end{array}$ & Ниш \\
\hline $\begin{array}{c}\text { Друшт- } \\
\text { вена по- } \\
\text { жељност }\end{array}$ & 2,0882 & 5,1176 & 2,1887 & 5,4706 & 2,3260 & 5,1348 & 2,1152 & 4,8358 \\
\hline $\begin{array}{c}\text { Солидар- } \\
\text { ност }\end{array}$ & 4,8873 & 2,4804 & 5,2451 & 2,5025 & 5,1863 & 2,5539 & 5,1446 & 2,2328 \\
\hline $\begin{array}{c}\text { Језичка } \\
\text { исправ- } \\
\text { ност }\end{array}$ & 1,9657 & 4,1569 & 2,1765 & 4,9338 & 2,2549 & 4,1740 & 2,1029 & 3,6863 \\
\hline
\end{tabular}

\subsection{1. Резултати истраживања спроведеног у Нишу}

Дијалекатска припадност испитаника била је варијабла коју смо узели као значајну у нашем истраживању у жељи да видимо и покажемо да ли постоје разлике у оцењивању варијетета српског језика код испитаника који живе у регионално блиским, али дијалекатски различитим подручјима.

Табела 3. Средње вредности за дванаест оцењениваних особина (на подручју Ниша)

\begin{tabular}{|c|c|c|c|c|c|c|c|c|}
\hline Особине & $\begin{array}{c}\text { Бео- } \\
\text { град }\end{array}$ & $\begin{array}{c}\text { Кру- } \\
\text { шевац }\end{array}$ & $\begin{array}{c}\text { Нови } \\
\text { Сад }\end{array}$ & $\begin{array}{c}\text { Пи- } \\
\text { рот }\end{array}$ & $\begin{array}{c}\text { Апа- } \\
\text { тин }\end{array}$ & Блаце & $\begin{array}{c}\text { Субо- } \\
\text { тица }\end{array}$ & Ниш \\
\hline $\begin{array}{c}\text { Образо- } \\
\text { вана }\end{array}$ & 1,9583 & 5,2083 & 1,9583 & 5,9583 & 2,3750 & 5,2917 & 1,8542 & 4,8333 \\
\hline $\begin{array}{c}\text { Дружељу- } \\
\text { бива }\end{array}$ & 4,7292 & 2,6042 & 4,7500 & 2,7292 & 5,1042 & 2,9375 & 5,0625 & 2,1875 \\
\hline $\begin{array}{c}\text { Интели- } \\
\text { гентна }\end{array}$ & 2,2292 & 5,2500 & 1,8958 & 5,5833 & 2,0833 & 5,3333 & 1,9792 & 4,8125 \\
\hline Искрена & 4,8333 & 2,4583 & 4,9167 & 2,6458 & 5,2500 & 2,7708 & 5,1250 & 2,0208 \\
\hline Успешна & 2,0208 & 5,5000 & 1,9375 & 5,6667 & 1,9375 & 5,5417 & 1,7917 & 6,0000 \\
\hline Поуздана & 5,2500 & 2,7083 & 6,3958 & 2,7500 & 5,3958 & 2,6458 & 5,3958 & 1,9167 \\
\hline Стручна & 2,2708 & 5,6875 & 2,5625 & 5,9792 & 2,3958 & 5,9792 & 2,3333 & 5,3333 \\
\hline
\end{tabular}




\begin{tabular}{|c|c|c|c|c|c|c|c|c|}
\hline Духовита & 6,3125 & 2,4375 & 6,4167 & 1,9792 & 6,3542 & 2,6458 & 6,4583 & 1,6458 \\
\hline Исправна & 1,6667 & 5,5000 & 2,0833 & 6,3750 & 1,7917 & 5,1458 & 1,7083 & 4,5625 \\
\hline Пријатна & 2,7083 & 3,6458 & 2,7500 & 4,0625 & 3,6042 & 5,4792 & 2,6667 & 3,0833 \\
\hline Стандардна & 2,3333 & 4,9375 & 1,9583 & 5,4583 & 1,9583 & 4,6458 & 1,9792 & 4,3125 \\
\hline Разумљива & 1,7917 & 3,5000 & 1,9375 & 3,6667 & 2,0208 & 3,6042 & 1,6458 & 2,2917 \\
\hline
\end{tabular}

Испитаници из Ниша оценили су суботички варијетет као најповољнији у смислу друштвене атрактивности, док је најнегативније оцењен пиротски варијетет. Најпоузданији и емоционално најближи за њих био је нишки варијетет, док им је најдаљи био новосадски. Нишки средњошколци су суботички варијетет видели у најповољнијем светлу када су у питању лингвистичке перформансе, док је најнеповољније оцењен пиротски варијетет.

Табела 4. Средюе вредности за дванаест особина груписаних у три подручја - на територији Ниша

\begin{tabular}{|c|c|c|c|c|c|c|c|c|}
\hline Груписано & $\begin{array}{c}\text { Бео- } \\
\text { град }\end{array}$ & $\begin{array}{c}\text { Кру- } \\
\text { шевац }\end{array}$ & $\begin{array}{c}\text { Нови } \\
\text { Сад }\end{array}$ & $\begin{array}{c}\text { Пи- } \\
\text { рот }\end{array}$ & $\begin{array}{c}\text { Апа- } \\
\text { тин }\end{array}$ & $\begin{array}{c}\text { Бла- } \\
\text { це }\end{array}$ & $\begin{array}{c}\text { Субо- } \\
\text { тица }\end{array}$ & Ниш \\
\hline $\begin{array}{c}\text { Друштвена } \\
\text { пожельост }\end{array}$ & 2,1198 & 5,4115 & 2,0885 & 5,7969 & 2,1979 & 5,5365 & 1,9896 & 5,2448 \\
\hline $\begin{array}{c}\text { Соли- } \\
\text { дарност }\end{array}$ & 5,2812 & 2,5521 & 5,6198 & 2,5260 & 5,5260 & 2,7500 & 5,5104 & 1,9427 \\
\hline $\begin{array}{c}\text { Језичка } \\
\text { исправност }\end{array}$ & 2,1250 & 4,3958 & 2,1823 & 4,8906 & 2,3437 & 4,7188 & 2,000 & 3,5625 \\
\hline
\end{tabular}

\subsection{2. Резултати истраживања спроведеног у Блацу}

Табела 5. Средње вредности за дванаест оцењениваних особина (на подручју Блаиа)

\begin{tabular}{|c|c|c|c|c|c|c|c|c|}
\hline Особине & $\begin{array}{c}\text { Бео- } \\
\text { град }\end{array}$ & $\begin{array}{c}\text { Кру- } \\
\text { шевац }\end{array}$ & $\begin{array}{c}\text { Нови } \\
\text { Сад }\end{array}$ & $\begin{array}{c}\text { Пи- } \\
\text { рот }\end{array}$ & $\begin{array}{c}\text { Апа- } \\
\text { тин }\end{array}$ & $\begin{array}{c}\text { Бла- } \\
\text { це }\end{array}$ & $\begin{array}{c}\text { Субо- } \\
\text { тица }\end{array}$ & Ниш \\
\hline Образована & 1,6296 & 4,7593 & 2,0370 & 5,0741 & 2,0926 & 4,6852 & 2,0000 & 4,2593 \\
\hline $\begin{array}{c}\text { Друже- } \\
\text { љубива }\end{array}$ & 3,7407 & 2,4630 & 4,3333 & 2,7222 & 4,3333 & 2,6481 & 4,3148 & 2,4444 \\
\hline
\end{tabular}




\begin{tabular}{|c|c|c|c|c|c|c|c|c|}
\hline $\begin{array}{c}\text { Интели- } \\
\text { гентна }\end{array}$ & 2,2778 & 4,6481 & 2,2778 & 4,9259 & 2,3889 & 4,6852 & 2,1852 & 4,2037 \\
\hline Искрена & 4,2778 & 2,1296 & 4,7778 & 2,4444 & 4,6852 & 2,3889 & 4,6481 & 2,4259 \\
\hline Успешна & 2,0926 & 4,7037 & 2,2593 & 5,1852 & 2,7593 & 4,6667 & 2,2593 & 4,5926 \\
\hline Поуздана & 4,4630 & 2,5556 & 4,7407 & 2,7778 & 4,7593 & 2,2963 & 4,7037 & 2,7778 \\
\hline Стручна & 2,2407 & 5,3148 & 2,5370 & 5,5370 & 2,5185 & 5,0741 & 2,4630 & 4,8333 \\
\hline Духовита & 5,6667 & 2,5185 & 5,7963 & 1,9815 & 5,7593 & 2,1852 & 5,6111 & 2,3148 \\
\hline Исправна & 1,4815 & 5,2778 & 1,9444 & 6,0185 & 2,0556 & 4,8889 & 1,9630 & 4,6852 \\
\hline Пријатна & 2,4259 & 3,4815 & 2,6481 & 4,1111 & 2,8148 & 3,2778 & 2,7778 & 3,1852 \\
\hline Стандардна & 2,0000 & 4,8333 & 2,3519 & 5,8519 & 2,0926 & 4,4630 & 2,2037 & 4,5741 \\
\hline Разумљива & 1,3889 & 2,1852 & 1,7407 & 3,9074 & 1,7407 & 2,1296 & 1,8333 & 2,7407 \\
\hline
\end{tabular}

Блачки средњошколци су видели београдски варијетет као друштвено најпожељнији и најцењенији, док се на последњем месту налази пиротски варијетет. Прво место у домену солидарности заузима блачки варијетет, док је новосадски младим средњошколцима био најмање близак и искрен. Београдски варијетет оцењен је као лингвистички најпожељнији, док је као најмање „тачан и исправан” оцењен пиротски варијетет.

Табела 6. Средње вредности за дванаест особина груписаних у три подручја - на територији Блача

\begin{tabular}{|c|c|c|c|c|c|c|c|c|}
\hline Груписано & $\begin{array}{c}\text { Бео- } \\
\text { град }\end{array}$ & $\begin{array}{c}\text { Кру- } \\
\text { шевац }\end{array}$ & $\begin{array}{c}\text { Нови } \\
\text { Сад }\end{array}$ & $\begin{array}{c}\text { Пи- } \\
\text { рот }\end{array}$ & $\begin{array}{c}\text { Апа- } \\
\text { тин }\end{array}$ & $\begin{array}{c}\text { Бла- } \\
\text { це }\end{array}$ & $\begin{array}{c}\text { Субо- } \\
\text { тица }\end{array}$ & Ниш \\
\hline $\begin{array}{c}\text { Друштвена } \\
\text { пожељност }\end{array}$ & 2,0602 & 4,8565 & 2,2778 & 5,1806 & 2,4398 & 4,7778 & 2,2269 & 4,4722 \\
\hline $\begin{array}{c}\text { Соли- } \\
\text { дарност }\end{array}$ & 4,5370 & 2,4167 & 4,9120 & 2,4815 & 4,8843 & 2,3796 & 4,8194 & 2,4907 \\
\hline $\begin{array}{c}\text { Језичка } \\
\text { исправност }\end{array}$ & 1,8241 & 3,9444 & 2,1713 & 4,9722 & 2,1759 & 3,6898 & 2,1944 & 3,7963 \\
\hline
\end{tabular}

Теоријски предвиђена ситуација односи се на чињеницу да су испитаници сопствене варијетете оцењивали позитивно у домену солидарности, док су их негативно оцењивали у друштвеном и језичком погледу. И блачки и нишки варијетети налазили су се на првом месту у другој групи особина, али је за- 
нимљиво да скорови у табелама показују да су се на другом месту налазили крушевачки, односно, пиротски варијетет, што показује да су регионална и дијалекатска блискост битне димензије у оцењивању варијетета.

Обрадом добијених података установљено је да у истраживању постоје статистички значајне разлике за дванаест особина с обзиром на место живљења $(T$ mecm). Испитаници из Ниша процењују бољим нишки варијетет у домену искрености (сиг. $=0,043$, п $<0,05)$, што је и очекивано, с обзиром да су свој варијетет оценили као најбољи у погледу солидарности, интелигентности (сиг. $=0,038, \Pi<0,05)$, пријатности (сиг. $=0,046, \Pi<0,05)$ и стандардности (сиг. $=$ $0,020, \Pi<0,05)$. Нишки средњошколци веома повољно оцењују разумљивост код пиротског варијетета (сиг. $=0,004$, п <0,01), што потврђује нашу хипотезу да се локално блиски варијетети оцењују повољно и у домену солидарности и у домену разумљивости. О томе говоре и добијени подаци везани за испитанике из Блаца: они су блачки варијетет процењивали боље у домену разумљивости (сиг. $=0,000, \Pi<0,01)$, али и у свим оним сегментима који се односе на друштвену пожељност - образованост (сиг. $=0,027$, п $<0,05)$, стручност (сиг. $=0,000, \Pi<0,01)$, интелигентност (сиг. $=0,009$, п $<0,01)$, успешност (сиг. $=$

0,017, п<0,05). Примећујемо да је виђеност друштвено пожељних придева код блачког варијетета (од стране блачких средњошколаца) статистички значајна и када погедамо резултате код груписаних придева: друштвена пожељност сиг. $=0,002$, п < 0,01. Крушевачки варијетет блачки средњошколци виде као разумљивији (сиг. $=0,000, \Pi<0,01)$ у односу на испитанике из Ниша, те и у овом случају имамо исту ситуацију као и са пиротским варијететом: регионална и дијалекатска блискост показале су се битним што је и статистички потврђено.

\subsection{3. Факторска анализа коришћених придева при прављењу семантичко-диференцијалне скале}

У радовима оваквог типа значајно место има факторска анализа која је показатељ да ли је наша теоријска замисао била ваљана и да ли је одабир придева био исправан и примерен истраживању (Хирага 2005). Желели смо да видимо да ли су одабрани придеви јасно распоређени у три димензије - друштвена пожељност, солидарност и лингвистичке перформансе. И у овом случају коришћен је статистички метод. Пошто је било више од једног фактора - у овом случају три, они су ротирани коришћењем Варимакс методе (Varimax metod). 
Табела 7. Резултати факторске анализе за особине коришћене у истраживану

\begin{tabular}{|c|c|c|c|}
\hline \multirow{2}{*}{ Придеви } & \multicolumn{3}{|c|}{ Компоненте (Фактори) } \\
\cline { 2 - 4 } & 1 & 2 & 3 \\
\hline Образована &, 652 &, 558 &, 166 \\
\hline Дружељубива &, 349 &, 797 &, 142 \\
\hline Интелигентна &, 679 &, 496 &, 174 \\
\hline Искрена &, 248 &, 813 &, 179 \\
\hline Успешна &, 588 &, 360 &,- 054 \\
\hline Поуздана &, 212 &, 508 &, 449 \\
\hline Стручна &, 765 &, 249 &, 295 \\
\hline Духовита &, 770 &, 083 &, 179 \\
\hline Исправна &, 511 & -023 &, 711 \\
\hline Пријатна &, 518 &, 254 &, 415 \\
\hline Стандардна &, 213 &, 121 &, 816 \\
\hline Разумљива &,- 121 &, 444 &, 664 \\
\hline
\end{tabular}

Резултати показују да се теоријска замисао у високом степену показала тачном у пракси и да је одабир придева био адекватан, изузев два која би захтевала и додатна испитивања - путем интервјуисања испитаника и сагледавањем ширег контекста њихових значења. Најпре, да се осврнемо на факторски „чисте” особине. Сви придеви из групе друштвено пожељних и „статусних” придева у потпуности су нашли своје место и показали се као адекватни за овакву врсту истраживања. Образованост, интелигентност, успешност и стручност, испитаници су видели као равноправне и једнаке када говоримо о особинама које сваки појединац прижељкује да поседује. У другој групи придева, испитаници су дружељубивост, искреност и поузданост видели као најадекватније приликом оцењивања особа које су сматрали блиским. На крају, исправност, стандардност и разумьивост показали су се примереним за описивање лингвистичке стране нечијег говора.

Придев духовита испитаници нису видели као ми. Анализа ученичких одговора показује да је његово место у првој групи, са осталим професионалним придевима. Дакле, они духовитост везују за образовање и интелигенцију, 
иако смо сматрали да ће је везивати за приватни контекст. Исту ситуацију имамо и са придевом пријатна, који је требало да се према нашем мишљењу нађе у трећој групи. Међутим, испитаници и њега виде као један од пожељних и атрактивних придева. Разлоге за овакву ситуацију треба тражити узимајући у обзир контекст и културолошки аспект, а као што је речено, додатна испитивања би то и пружила.

\section{2. Други део истраживања: упитник ${ }^{10}$}

На прво питање (Да ли је важно имати добар изговор?) највећи број испитаника је имао позитиван став, тј. 85,3\% од укупног броја сматра да је важно имати добар изговор. Међутим, (Да ли сте се икада осећали дискриминисаним због свог нагласка?) чак 74,5\% испитаника наводи да се нису осећали дискриминисаним због нагласка, иако смо очекивали да ће тај проценат бити мањи с обзиром да су у питању људи са дијалекатски доста удаљених подручја од стандрадних. Одговори на треће питање (Да ли ти смета када разговараш са некиме ко има теби стран нагласак?) показују да је већина младих $(65,7 \%)$ толерантна према различитим варијететима српског језика и да им нагласак није пресудан у разговору с некиме. На питање Да ли би био поносан и задовољан да те према нагласку препознају као Нишлију/Блачанина? чак $67,7 \%$ испитаника одговорило је потврдно, што указује на чињеницу да свој варијетет виде у позитивном светлу и исказују понос због свог регионалног порекла - овоме у прилог иду и неки „спољни” елементи које смо запазили током истраживања и рада на терену, а то су узвичници поред заокруженог да, звездице, болдирани кругови, који, свакако, појачавају исказани степен задовољства.

Петим питањем (Да ли мењаш свој нагласак када раговараш са људима из других крајева Србије?) испитаници су показали да су верни свом варијетету и да се служе њиме и када разговарају са вршњацима из других крајева Србије - 57,8\% њих не мења свој нагласак. Међутим, 25,5\% њих изјавило

${ }^{10}$ Дистрибуција петостепених одговора налази се у фусноти, због простора. Распоред одговора код првог питања: одговор да - 30 испитаника, углавном да 57, само понекад 11, углавном не 3 и одговор не имао је 1 испитаник; код другог питања: одговр да- 4 испитаника, углавном да 2, само понекад 20, углавном не 25 и одговор не имао је 51 испитаник); распоред одговора код трећег питања: да - 6 испитаника, углавном да 3, само понекад 26, углавном не 30 и одговор не имало је 37 испитаника; распоред одговора код четвртог питања: да - 57 испитаника, углавном да 12, само понекад, углавном не 11 и не 11 испитаника; распоред одговора код петог питања: одговор да - 3 испитаника, углавном да 14 , само понекад 26, углавном не 10 и одговор не имало je 49 испитаника; распоред одговора код шестог питања: да - 10 испитаника, углавном да 8, само понекад 17, углавном не 19 и одговор не имало је 48 испитаника; распоред одговора код седмог питања: одговор да - 4 испитаника, углавном да такође 4, само понекад 11, углавном не 31 испитаник и не 52 испитаника. На крају, на осмо питање одговор да имао је 21 испитаник, углавном да 14, само понекад 12, углавном не 15 и одговор не имало је 40 испитаника. 
је да само понекад мења свој нагласак што је, ипак, довољно да покаже да постоји промена. ${ }^{11}$

Последња три питања конструисана су из жеље да се види на који начин средњошколци оцењују говор својих професора у школама и новинара на локалним телевизијама и радио станицама - да ли су за њих наведена занимања и институције носиоци правилности у говору. На шесто питање (Да ли сматраш да твој професор српског језика треба да користи стандрадну варијанту српског језика док предаје?) 65,7\% ученика је одговорило негативно, док је на седмо питање (Да ли сматраш да твоји професори из осталих предмета треба да користие стандрадну варијанту српског језика док предају?) чак $81,4 \%$ одговорило, такође, негативно. Процентуална разлика између шестог и седмог питања (15,7\% у корист другог) указује на чињеницу да ученици сматрају да професори српског језика треба да буду носиоци лепог говора, у односу на друге професоре. Занимљива је процентуално неубедљива негативност код последњег питања у односу на претходна два (Да ли ти смета када новинари локалних телевизија не употребљавају стандрадну варијанту српског језика?) - 53,9\% испитаника одговорило је негативно, а 34,3\% позитивно. Овакав распоред одговора указује на чињеницу да средњошколци сматрају да су новинари носиоци лепог говора и дају им предност у томе у односу на професоре у школи.

Статистичка закључивања: постоји статистички значајна корелација између места живљења и старости - 0,358 на нивоу п <0,01 (Пирсонова корелација), али не постоји између датих одговора и места живљења испитаника. Дистрибуција одговора према градовима је слична: сви испитаници су у истој мери видели постављена питања.

\section{5. ИНТЕРПРЕТАЦИЈА РЕЗУЛТАТА}

1. Наши испитаници су показали велики степен позитивности и према сопственим и према осталим варијететима српског језика, када су у питању одговори добијени помоћу упитника, али и додељивањем високих оцена за разумљивост свим говорницима: скорови везани за особине из области језичке исправности указују на чињеницу да је ова особина оцењена најпозитивније у односу на остале. То је и очекивано - да варијетети матерњег језика буду разумљиви. Са друге стране, иако су испитаници поносни на нагласне особине сопственог варијетета, они имплицитним одговрима показују да га у позитивном светлу виде само онда када је у питању емоционална блискост

${ }^{11}$ Испитаници су наводили да мењају свој нагласак када „разговарају са особама женског пола” и када су „у комуникацији са људима из севернијих крајева”. 
и повезаност са њиме, док са друге стране испољавају негативан став према истом у погледу професионалности и језичке исправности (Лејдгард 1998; Мекензи 2008; Хирага 2005).

2. Сви новоштокавски варијетети оцењени су позитивно у домену друштвене пожељности (добијени скорови су приближне вредности), што указује на то да су средњошколци кроз говор, тј. кроз нагласне елементе видели говорнике као „успешне људе” или „поуздане особе”. Интересантно је да су испитаници најпозитивније оцењивали образованост и успешност код говорника, док су скорови за интелигентност и стручност нижи - дакле, они сматрају да су такве особе веома успешне због свог говора и да је он огледало образовања, док су интелигенцију и стручност у нешто мањој мери видели као особине које су директно везане са говором људи.

3. Пиротски варијетет најнегативније је оцењен у погледу професионалности и друштвене атрактивности, као и у домену лингвистичких перформанси, што је занимњиво из два разлога: прво, испитаници су свесни да је у питању варијетет који је по својим одликама најудаљенији од стандардног и да се највише неправилности на прозодијском нивоу уочава у њему; друго, нишки варијетет нису повезивали са пиротским и уочавали су разлике међу њима - испитаници из Ниша су у највећем броју случајева препознали да је у питању пиротски варијетет и у отвореним коментарима изражавали незадовољсто што говорници из централних и северних крајева све јужњачке варијетете сврставају у нишки, а разлике су очигледне.

4. Језичке особине оцењиваних варијетета показују да оно што су видели као друштвено пожељно, испитаници нису видели као језички исправно: добијени скорови за исправност, пријатност и стандардност виши су у односу на скорове везане за друштвено пожељне особине, што значи да су они неповољније оцењени. Дакле, испитаници немају јасну представу о томе шта је језички тачно. Не можемо, а да се не осврнемо на тумачење појмова језичке исправности и стандардности. Резултати нашег истраживања показују да је стандардност неповољније оцењена од исправности (као и код Лејдгарда 1998) и да су скорови нешто виши у том домену, што значи да ниједан варијетет није убедљиво оцењен као стандардни. Дакле, испитаници све новоштокавске говоре сматрају исправним, али не и стандардним.

5. Сви испитаници одлучно заступају став да треба чувати и неговати свој локални говор и да га не треба мењати и у оним ситуацијама када су им саговорници особе које говоре другачијим варијететом. Они су професоре и новинаре, такође, видели као људе који треба да чувају свој локални говор, без обзира на професију која захтева употребу стандардног језика. Ови подаци охрабрују, када је у питању позитиван однос према сопственом говору, али не и степен граница до којих тај однос иде. Међутим, подсећамо да су 
индиректном методом показали да људе из сопственог окружења не виде као професионалне, те на тај начин уочавамо да се експлицитни и имплицитни ставови испитаника разликују.

\section{6. ЗАКЉУЧАК}

Резултати истраживања спроведеног на примеру српског језика поклапају се са резултатима везаним за енглески језик - испитивану појаву, донекле, можемо тумачити као генералну чињеницу на нивоу свих језика, с тиме што су одређене финесе, занимљивости и ситуације условљене друштвеним и културолошким одликама сваке земље. Испитаници су показали да су им нагласне особине веома битне и да играју важну улогу у перцепцији и сагледавању говора сваког појединца, односно, његове целокупне личности - резултати показују да су људи осетљиви на језичке варијетете и да, позитивно или негативно, реагују на њих. Неповољним оценама јужњачких варијетета испитаници показују да велику улогу играју стереотипи и идеологија.

Ако о ставовима говоримо као о вредносним реакцијама на одређене језике или варијетете унутар једног језика, не можемо а да не истакнемо њихов вишеструки значај: веома су важан фактор у друштвеним интеракцијама и тесно су повезани са перцепцијом друштвене моћи и солидарности; имају велику улогу у обликовању језичког, друштвеног, социјалног и културног идентитета појединца; представљају драгоцене смернице у креирању језичке политике. Потребно је интердисциплинарним и детаљним истраживањима, уз коришћење већег броја социјалних и лингвистичких варијабли, наставити испитивање ставова према језичким варијететима како би добијена слика била проширена и експериментално употпуњена.

\section{ЛИТЕРАТУРА}

Бјелаковић и Марковић 2009: И. Бјелаковић и М. Марковић, Послеакценатска дужина у говору Новог Сада, у: Ж. Бошњаковић (ред.), Говор Новог Сада, Свеска I: Фонетске особине, Лингвистичке свеске 8, Нови Сад: Филозофски факултет у Новом Саду, 110-129.

Бошњаковић 2009: Ж. Бошњаковић, Преношење акцената на проклитику у говору Новог Сада, y: Ж. Бошњаковић (ред.), Говор Новог Сада, Свеска I: Фонетске особине, Лингвистичке свеске 8, Нови Сад: Филозофски факултет у Новом Саду, 79-110.

Бугарски 2009: Р. Бугарски, Теоријске основе урбане дијалектологије, $y:$ Ж. Бошњаковић (ред.), Говор Новог Сада, Свеска I: Фонетске осо- 
бине, Лингвистичке свеске 8, Нови Сад: Филозофски факултет у Новом Саду, 13-31.

Васић 1994: В. Васић, Ставови према језику у граматичким приручницима српскохрватског језика, Нови Сад: Зборник Матище српске за филологију и лингвистику XXXVII/1-2, 109-118.

Ивић 1985: П. Ивић, Дијалектологија српскохрватског језика: Увод и штокавско наречје. Друго издање. Нови Сад: Матица српска.

Ивић 1994: П. Ивић, Српскохрватски дијалекти: њихова структура и развој, Књига I, Општа разматрања и штокавско наречје, Сремски Карловци - Нови Сад: Издавачка књижарница Зорана Стојановића.

Књижар 2011: И. Књижар, Ставови Новосађана према месном говору и стандардном језику, $y:$ В. Васић и Г. Штрбац (ред.), Говор Новог Сада, Свеска 2, Морфосинтаксичке, лексичке и прагматичке особине, Нови Сад: Филозофски факултет у Новом Саду, 361-378.

Ковачевић 2004: Б. Ковачевић, Ставови према варијететима српског језика, Philologia, 2, 22-38.

Ковачевић 2005: Б. Ковачевић, Ставови говорника српског језика према страним језицима, Београд: Српски језик, X/1-2, Београд, 501-518.

Средојевић 2011: Д. Средојевић, Препознавање новосадског изговора и ставови према њему, $y$ : В. Васић и Г. Штрбац (ред.), Говор Новог Сада, Свеска 2, Морфосинтаксичке, лексичке и прагматичке особине, Нови Сад: Филозофски факултет у Новом Саду, 378-399.

Суботић 2005: Љ. Суботић, Ортоепска норма - данас. Београд: Научни састанак слависта у Вукове дане, XXIV/1: 311-317.

\section{$* * *$}

Купланд и Бишоп 2007: N. Coupland and H. Bishop, Ideologised values of British Accents, Journal of Sociolinguistics XI/1, 74-93.

Фергусон 1991: Ch. Ferguson, Epilogue: Diglossia revisited, Southwest Journal of Linguistics, X/1, 214-234.

Гарет, Купланд и Вилијамс 2003: P. Garrett, Peter, N. Coupland \& A. Williams. Investigating Language Attitudes: Social Meanings of Dialect, Ethnicity and Performance. Cardiff: University of Wales Press.

Хауард и Купланд 1991: G. Howard and N. Coupland, Language contexts and Consequences, Milton Keynes: Open University Press. 
Хирага 2005: Y. Hiraga, British attitudes towards six varieties of English in the USA and Britain, World Englishes, XXIV/3, 289-308.

Лабов 1972a: W. Labov, Language in the Inner City: Studies in the Black English Vernacular, Philadelphia: University of Pennsylvania Press.

Лабов 1972б: W. Labov, Sociolingustic Patterns, Philadelphia: University of Pennsylvania Press.

Лејдгард 1998: H. Ladegaard, National stereotypes and language attitudes: the perception of British, American and Australian language and culture in Denmark, Language and Communication XVIII, 251-274.

Мекензи 2008: R. McKenzie, Social factors and non-native attitudes towards varieties of spoken English: a Japanese case study, International Journal of Applied Linguistics, XVIII/1, 63-88.

Милрој 2001: L. Milroy, The social categories of race and class: language ideology and sociolinguistics, in: N. Coupland, S. Sarangi \& C.N. Candlin (eds.), Sociolinguistics and Social Theory. London: Routledge, $16-39$.

Пауновић 2007a: T. Paunović, Jezik u procepu - između tradicije i globalizacije, $u$ : R. Simić, D. Ivanić i M. Kovačević (red.), Srpski jezik, književnost i umetnost, Knjiga I, Srpski jezik i društvena kretanja, Kragujevac: Filološko-umetnički fakultet, 317-357

Пауновић 2007б: T. Paunović, Jezik i identitet: Život između dva jezika, Zbornik radova Anglistika danas, Interkatedarska konferencija Departmana za anglistiku, Niš: Filozofski fakultet Univerziteta u Nišu, 21-37.

Пауновић 2008: T. Paunović, Globalization on the tip of my (mother) tongue. In the Proceedings of the international conference Language, Literature, Globalization, Nis: Faculty of Philosophy, University of Nis, 43-66.

Пауновић 2009a: T. Paunović, Plus Ça Change... Serbian EFL Students' Attitudes Towards Varieties of English, Poznan Studies in Contemporary Linguistics, XLV/4, 525-547.

Пауновић 2009б: T. Paunović, Sociolingvistički pogled u susedovo dvorište: stavovi prema jezičkim varijetetima, $u$ : M. Kovačević (red.), Radovi Filozofskog fakulteta, broj 11, knjiga 1 (Filološke nauke) Pale: Univerzitet u Istočnom Sarajevu, Filozofski fakultet Pale.

Традгил 1983: P. Trudgill, Dialect, Social and Geographical Perspectives, Oxford: Blackwell. 


\title{
HIGH SCHOOL STUDENTS' ATTITUDES TOWARDS EIGHT URBAN VARIETES OF SERBIAN
}

\begin{abstract}
Summary
Attitudes towards language varieteties represent very important factors in social interaction, and are closely related to the perception of the social status, power and solidarity, as well as distance, especially when it comes to the prosodic features of speech. The paper presents the attitudes of 102 high school students, from the territory of Niš and Blace, towards eight urban varieties of Serbian, belonging to the Neo-Shtokavian dialect, the OldShtokavian dialect and Prizren-Timok dialect. For the purpose of the research, eight native speakers of different varieties were recorded (the VGT technique) and using both indirect (semantic-difference scale) and direct (questionnaire) methods it was shown that the subjects' explicit and implicit attitudes differ as well as that an individual's manner of speaking affects the participants' perception and assignment of traits regarding the social status, solidarity and linguistic performance.

Key words: sociolinguistics, language attitudes, Serbian, language varieties, explicit/ implicit attitudes, traits, social power, solidarity, correctness.
\end{abstract}

Nina Sudimac 